\title{
Udbin dosje kao povijesni izvor - slučaj Vujičić
}

\author{
Branko Salaj \\ branko.salaj@gmail.com
}

SAŽETAK: U početku svibnja 1941. skupina mladih ustaša pri Ustaškom stanu u Karlovcu uhitila je i ubila trojicu Srba. Afera, poznata i kao slučaj Vujičić (prema Milanu Vujičiću, najpoznatijoj žrtvi, odvjetniku i političaru) svojedobno je zataškana, no u historiografiji i publicistici ostavila je dubljega traga od nekih većih zlodjela. U proljeće 1947. Jugoslaviji je izručen Vladimir Židovec, diplomat Nezavisne Države Hrvatske (NDH), koji je u doba zločina bio tajnik karlovačkoga Ustaškog stana. On je podvrgnut intenzivnoj istrazi u kojoj je ponudio i svoju suradnju. U poduljem i višestruko upitnom svjedočenju on je kao inicijatora zločina teretio svojega lokalnog suparnika, predsjednika Stana Antu Nikšića, koji je i sâm završio u diplomatskoj službi NDH, ali je neko vrijeme bio i ministar unutarnjih poslova. Unatoč raznim dvojbenim pojedinostima istrage, na tezi prema kojoj je Nikšić potaknuo ubojstvo svojega osobnog prijatelja Vujičića ustraje se već desetljećima. Kao navodno neprijeporna činjenica našla je put u leksikografsku literaturu, a i poslužila u poopćenim kontekstualizacijama. U članku se stoga na osnovu nekih novih saznanja nastoji ponovno razmotriti cijeli slučaj, ne radi konačnoga odgovora, već kako bi se upozorilo na nužnost suzdržanijih interpretacija, kad se one odnose na materijale koji su imali zadovoljiti potrebe tajnih službi.

Ključne riječi: Nezavisna Država Hrvatska; Karlovac; Milan Vujičić; Ante Nikšić; Vladimir Židovec; Udba

\section{Uvod*}

Dne 5. svibnja 1941. na večer skupina mladih ustaša, formalno pomoćni sastav policije a funkcionalno pridružena Ustaškom stanu u Karlovcu, uhitila je i u okolici grada ubila odvjetnika dr. Milana Vujičića, kapetana jugoslavenske vojske Gojka Janjanina i željezničara Dušana Dokmanovića. Najpoznatiji je među njima bio Vujičić, dugogodišnji predsjednik karlovačke podružnice Samostalne demokratske stranke.

Slučaj je aktualiziran nakon što su britanske vlasti u Italiji 27. travnja 1947. Jugoslaviji izručile dr. Vladimira Židovca, negdašnjega tajnika Ustaškoga stana u Karlovcu. Suočen s mogućnošću likvidacije, Židovec je jugoslavenskim vlastima po-

* Ovom prigodom trima recenzentima časopisa Studia lexicographica zahvaljujem na korisnim primjedbama koje sam u najvećoj mjeri nastojao ugraditi u konačnu inačicu rada. 
nudio suradnju, a one su uočile da bi ga vezano uz tzv. slučaj Vujičić mogle iskoristiti kao svjedoka u mogućem zahtjevu za izručenje dr. Ante Nikšića, negdašnjega predsjednika toga Ustaškoga stana, koji je potom za NDH bio veliki župan, generalni konzul u Beogradu, kraće vrijeme ministar unutarnjih poslova, poslanik u Rimu, šef odsjeka za međunarodnu suradnju u Ministarstvu vanjskih poslova i - potkraj rata - generalni konzul u Beču. ${ }^{1}$

Židovca, koji je nakon karlovačke epizode bio poslanik u Sofiji (1941-1943) i visoki dužnosnik u Ministarstvu vanjskih poslova NDH (1944-1945), ${ }^{2}$ intenzivno su obrađivali dvojica najviših istražitelja Udbe u Hrvatskoj, šef istražnoga centra Zvonko Ivanković Vonta i Mata Rajković. ${ }^{3} \mathrm{U}$ takvim okolnostima, Židovec je tijekom prvoga mjeseca provedenoga u zatvoru napisao autobiografiju Moje sudjelovanje u političkom životu (dalje: Autobiografija), u čijem se karlovačkom dijelu opširno bavi slučajem Vujičić. ${ }^{4}$ Autobiografija i drugi materijali o istražnom postupku prikupljeni su u opsežnom (357 str.), ali ipak nepotpunom Dosjeu Židovec, u jesen 1992. predanom Hrvatskom državnom arhivu. ${ }^{5}$

Prikazujući u Autobiografiji Nikšića kao potpuno nesposobnoga i nemoralnoga, pa i kao inicijatora ubojstava, Židovec je mogao biti pod sugestijom istražitelja, no iznimno negativne opće prosudbe o Nikšiću imao je - prema drugim izvorima - još za prvih tjedana $\mathrm{NDH}$ te se stječe dojam da ga ni intimno nije podnosio.

Kako bilo, istraga je okončana optužnicom u kojoj je odgovornost za smrt trojice karlovačkih Srba pripisana baš Židovcu, s obrazloženjem da sam priznaje kako je kontrolirao rad Ustaškoga stana u Karlovcu po čijim je direktivama djelovala policija, odnosno njezin odred mladih ustaša. ${ }^{6}$ Istom optužnicom Židovec je okriv-

1 Usp. Zdravko Dizdar, »Nikšić, Ante«, Tko je tko u NDH, Zagreb, Minerva, 1997., str. 296.

2 Usp. Mato Rupić, »Židovec, Vladimir«, ibid., str. 435.

3 Jedan njihov javno još poznatiji kolega, Slavko Odić, prisjećajući se toga slučaja napisao je u pismu Ivankoviću 30. siječnja 1994: »Davili ste Židovca kao zmija žabu« (preslika u posjedu B. S.).

4 Među ostalim, u Autobiografiji Židovec nagovara istražitelje na uvjetnu amnestiju budući da bi njegov »daljnji život za današnju Jugoslaviju ipak [bio] korisniji« jer su ga dvije godine u »emigraciji 'odgojile' više nego dva daljnja desetljeća normalnog života« odnosno eventualnog zatočeništva u zatvoru, i to na način »koji samo može konvenirati današnjim jugoslavenskim vlastima i politici, koju vodi Jugoslavija i komunistička stranka«. Navod prema Željko Karaula, Pavelićev diplomat na jugoistoku Europe, Bjelovar-Zagreb, Tiskara Horvat, 2017., str. 326.

5 HR-HDA-1561, SDS RSUP SRH, 013.0.56, Dosje Dr Vladimir Židovec (dalje: Dosje Židovec). Kad su Autobiografija i drugi istražni dokumenti dostupni u spomenutoj Karaulinoj knjizi ova studija kao izvor navodi tu publikaciju.

6 U obrazloženju se ističe da je Židovec na saslušanju 18. rujna 1947. izjavio: »na sjednicama [Ustaškog] stana obično [su] bile prihvaćane moje inicijative i moje ideje. [...] Tako sam prvih dana zapravo sve poslove vodio ja, a ostali članovi ravnali su se po mojim savjetima u svom radu [...] a sam dr. Nikšić proveo je veći dio vremena na svojim putovanjima u Zagreb i na stvaranju veza sa Zagrebom.« Karaula, str. 366. 
ljen i za postavljanje izvanrednoga narodnoga odnosno prijekoga suda u tzv. blagajskom slučaju. Suglasno optužnici, Okružni sud u Zagrebu je potkraj siječnja 1948. Židovca osudio na smrt, što je nakon dva tjedna potvrdio Vrhovni sud Narodne Republike Hrvatske, a odbijena je i molba za pomilovanje.

Međutim, premda je izvršenje kazne liječnički potvrđeno, postoje snažne indicije da je Židovec živio još godinama, služeći Udbi kao analitičar prilika u NDH te u ustaškom dijelu emigracije. Više od 90\% teksta u Dosjeu Židovec Židovčevi su vlastiti prilozi pisani za istražitelje ili odgovori na njihova pitanja. U širu inačicu Dosjea (ukupno 666 str.) dodani su i izvadci iz dviju studija o ustaškom režimu potpisanih pseudonimom Dizdar. Prema identifikaciji arhivista, a i nekih povjesničara, autor tih studija također je Židovec. ${ }^{8}$

Premda ne može dati potpuno i konačnu istinu o slučaju Vujičić, usporedbom Dosjea Židovec s drugim izvorima namjera je ovoga rada upozoriti po prvi puta na nekritička preuzimanja pojedinih teza, a onda još jednom i na to da poratni policijski i sudbeni postupci ne mogu poslužiti kao pouzdani pokazatelji stvarne kaznene odgovornosti pojedinaca jer su podlijegali trenutačnim političkim i operativnim prosudbama te uopće potrebama režima.

\section{Ustaški stan u Karlovcu}

Prema materijalima Dosjea Židovec, ilegalni Ustaški stan u Karlovcu osnovan je u veljači 1941. na inicijativu Slavka Kvaternika i domovinskoga ustaškog vodstva. Za predsjednika je izabran tadašnji predsjednik karlovačkoga Sudbenoga stola A. Nikšić, a za tajnika odvjetnik V. Židovec. Među članovima Stana, jedino su njih dvojica otprije bili članovi ustaškoga pokreta, a ostali su - među njima i Josip Berković, mjesni zapovjednik Hrvatske građanske zaštite - pristupili u tom trenutku, pri čemu navodno jedino dr. Feliks Židovec (Vladimirov otac, također odvjetnik) bez polaganja prisege.

Odmah nakon proglašenja NDH Stan je preuzeo vlast u gradu, razoružao garnizon jugoslavenske vojske te idućih mjesec i pol dana praktički upravljao upravnim i pravosudnim strukturama u gradu. U novim okolnostima na vidjelo je izbila

7 HR-HDA-1561, SDS RSUP SRH, 013.0.3 Dizdar, Ustaštvo i NDH i 013.1.3 Dizdar, Politički portreti.

8 Nada Kisić Kolanović, Zagreb-Sofija. Prijateljstvo po mjeri ratnog vremena 1941.-1945., Zagreb, Hrvatski državni arhiv-Dom i svijet, 2003, str. 267. U prilog autoričinoj tezi svakako idu i Židovčeva "posmrtna" pojavljivanja pod pravim imenom u drugim dosjeima te poklapanja njegovih ranijih izjava s onima pod pseudonimom Dizdar. Primjerice, Dizdar sudjeluje u pripremi zahtjeva za izručenje bivših visokih ustaških dužnosnika, pa tako npr. 31. kolovoza 1952. dovršava »Bilješke o slučaju dr. A. Artuković«, a sredinom lipnja 1954. razrađuje »drugu Cenčiću« neke argumente za izručenje Ante Pavelića. I grafološki nalaz po narudžbi Židovčeva sina potvrđuje istovjetnost rukopisa prije i poslije »pogubljenja«. Karaula, str. 54. 
podjela članova Stana između dvojice čelnih ljudi, Nikšića i V. Židovca, koji su se razlikovali ne samo generacijski nego i u drugim pogledima.

Dr. Ante Nikšić (1892-1962) politički se formirao u znaku pravaštva milinovske struje. Rođen je u Gospiću u uglednoj trgovačkoj obitelji a otac mu je bio jedan od vodećih pravaša u gradu i prijatelj Ante Starčevića. Pravo je studirao u Grazu i Beču te završio polaganjem rigoroza u Zagrebu, gdje je bio član upravnoga odbora akademskoga kluba »Kvaternik« i studentskoga potpornog društva. U njegovu odboru prijateljevao je s budućim poglavnikom Antom Pavelićem i budućim banom te jugoslavenskim predsjednikom vlade Ivanom Šubašićem. Isprva je radio na sudu, potom bio odvjetnik, uoči izbora 1925. predvodio korteširanje za Alberta Bazalu kao kandidata Hrvatskoga bloka. Nakon toga vratio se sudačkom zvanju, nije bio politički aktivan, biva često premještan, a 1934. postao je predsjednikom Sreskoga (kotarskoga) suda u Karlovcu. O svom uključivanju u ustaški pokret sâm Nikšić navodi da ga je potaknuo oduševljeni doček koji je 1937. u Karlovcu priređen predsjedniku iseljeničke Hrvatske bratske zajednice Ivanu Butkoviću, nakon čega je taj protjeran iz zemlje. ${ }^{9} \mathrm{U}$ pokret se uključio preko svojih starih zagrebačkih poznanika s uglavnom ličkim zaleđem, napose S. Kvaternika, Mile Budaka i Andrije Artukovića.

Stari Nikšićev prijatelj dr. Ivan Šubašić, tada angažiran u traženju hrvatsko-srpskoga sporazuma, premjestio je 1938. svoj odvjetnički ured u Karlovac. Putem doticaja na dvoru Karađorđevića Šubašić se zauzeo da se - kao primjer mogućnosti koje bi Hrvatima otvorio nov politički smjer - Nikšić imenuje predsjednikom novoutemeljenoga, drugostupanjskog Okružnog suda (poslije Sudbenoga stola) u Karlovcu. Moglo je pri tome pomoći i Nikšićevo prijateljstvo s vodećim karlovačkim srpskim političarem, odvjetnikom Milanom Vujičićem, ${ }^{10}$ ali i to što su dijelovi Nikšićeve pravaške obitelji svojedobno na dvoru bili dobro viđeni.

Antin ujak dr. Ivica Kovačević, koji je kao milinovski pravaš 1919. ušao u Hrvatsku zajednicu, bio je ministar šuma i ruda u vladama Kraljevstva Srba, Hrvata i Slovenaca 1920 (i jedan od posrednika između kralja Aleksandra i hrvatskih političara), ali i odvjetnik zatvorenoga Stjepana Radića 1925. ${ }^{11}$ Supruga Ivičina brata Matije, profesora gimnazije u Petrinji, kulturna i humanitarna djelatnica Zlata Lopašić-Kovačević nastupala je kao dvorska dama 1920-ih izrazito jugoslavenski, a bila je i potpredsjednica Oblasnoga odbora Jadranske straže u Zagrebu. ${ }^{12}$

9 Intervju »Iz dana, kad je Hrvatska iskrsnula«, Hrvatska sloboda, 2, 1941., 2. V, str. 2.

10 Autobiografija, prema Karaula, str. 110-111.

11 Nakon političke i odvjetničke karijere umirovljen kao vijećnik Stola sedmorice. Usp. Dino Mujadžević, »Kovačević, Ivica«, Hrvatski biografski leksikon, sv. 7, Zagreb, Leksikografski zavod Miroslav Krleža, 2009., str. 766.

12 Državni arhiv u Zagrebu, HR-DAZG-795 Jadranska straža. Odbor Zagreb. Zapisnici sastanaka Oblasnog odbora Jadranske straže u Zagrebu počam od konstituirajuće skupštine 23. XI. 1923. Usp. Ivica Golec, Petrinjski biografski leksikon, Petrinja, Matica hrvatska Petrinja, 1999., str. $230-231$. 
Za razliku od starijega Nikšića, dr. Vladimir Židovec (1907-?), sin poznatoga karlovačkog odvjetnika, i sâm odvjetnik, bio je karlovački starosjedilac, tijesno vezan uz grad. Tijekom odrastanja, uz živ intelekt i liberalan odgoj, oscilirao je u svojim nazorima. U Autobiografiji to ilustrira navodeći kako se kao gimnazijalac od buntovnoga ateista preobrazio u gorljivoga katolika, da bi, uz zadržano religijsko uvjerenje, u prvoj polovici 1930-ih, uz sestru Miru, postao pripadnik zagrebačkoga kruga komunističkih intelektualaca oko Zvonimira Richtmanna i Milana Durmana. Oko 1939. preko poznanstva s jednom studenticom završio je u društvu mlađih ustaških aktivista Ante Vokića i Aleksandra Seitza, usmjerenih na konkretno organizacijsko okupljanje. Židovčeva se poznanica potom udala za Božu Cerovskog, rodom Karlovčanina, koji je u NDH bio jedan od najbližih suradnika Eugena Dide Kvaternika. U kolovozu 1940. Židovec je položio ustašku zakletvu, a kao tajnik Ustaškoga stana početkom 1941. držao je na vezi i primio u pokret spomenutu grupu mladića koji su po Karlovcu ispisivali zabranjene ustaške parole te poslije postali pomoćni odred policije. ${ }^{13}$ Kao nadaren šahist i aktivan alpinist bio je nesumnjivo poznata osoba $u$ društvenom životu grada. ${ }^{14}$

\section{Sukob u Ustaškom stanu}

Vraćajući se iz talijanskoga egzila u Zagreb, Pavelić se sredinom travnja 1941. nepuna dva dana zadržao u Nikšićevu stanu u Karlovcu i u njemu pregovarao s visokim talijanskim i njemačkim izaslanicima. V. Židovec spominje da je već tih dana došlo do izraženijih napetosti između njega i Nikšića. Naime, osim što se Nikšić uputio u susret Paveliću a da nije sa sobom poveo ostale članove Ustaškoga stana, Židovec ga je okrivljavao i za to što nisu primljeni u posebnu audijenciju.

Nakon što je Stan počeo djelovati kao najviše tijelo lokalne političke vlasti, Nikšić je često boravio u Zagrebu, a Židovec je, prema vlastitoj izjavi udbaškim istražiteljima, potpuno preuzeo operativnu kontrolu nad radom Stana. Ustvari je on preuzeo i veći dio upravljanja gradom jer je njegov otac - imenovan gradonačelnikom - bio narušena zdravlja, pa ga je sin više puta zamjenjivao, primjerice kad je interese grada trebalo zastupati u Zagrebu. ${ }^{15}$

Početkom svibnja 1941. Stan je uz slučaj Vujičić zapljusnula i tzv. afera Blagaj. Naime, iste noći, 5. svibnja, kad su u okolici Karlovca ubijeni Vujičić i drugovi, u Hrvatskom Blagaju nepoznati su počinitelji ubili pet članova hrvatske obitelji mlinara Jose Mravunca. Židovec se navodno dan kasnije uključio u reagiranje vlasti na to

\footnotetext{
13 Karaula, str. 87.

14 Podatci o Židovcu uglavnom sažeti iz Autobiografije, prema Karaula, str. 66-93.

15 Karaula, str. 100-105, 366. Usp. bilj 6.
} 
ubojstvo, telefonski pronašao ministra pravosuđa Mirka Puka i od njega dobio ovlast odnosno nalog da za to imenuje izvanredni narodni (prijeki) sud. Kad je ministar 7. svibnja tu odluku svojim potpisom formalizirao i objavio, karlovački je sud - imenovan od Židovca - već bio na licu mjesta, utvrdivši tijekom dana da nisu provedene ozbiljnije istražne radnje i odgodivši uredovanje dok se one ne izvrše. Iz Zagreba je potom poslan sud u drugom sastavu koji je na smrt osudio 32 ljudi, a skupina ustaša, uglavnom povratnika iz Italije, smaknula je i velik broj drugih privedenih srpskih seljaka. ${ }^{16}$

Iz kratke naznake u Dosjeu može se zaključiti kako se Židovca u Zagrebu kritiziralo da je inicijativom u tom slučaju »podvalio« ministru Puku i da je tu karijerno neugodnu informaciju prenio upravo - Nikšić. ${ }^{17}$ Vjerojatno se očekivalo da će sudovanje izvanrednih narodnih odnosno prijekih sudova imati zastrašujući učinak pa je moguće da se Puku u vrhu vlasti predbacivalo da je »njegov«, a zapravo Židovčev sud podbacio svojim neuredovanjem. Međutim, u Židovčevoj Autobiografiji afera Blagaj spominje se vremenski i tematski potpuno odvojeno od slučaja Vujičić pa se tako izbjegava bilo kakvo uzročno-posljedično povezivanje tih dvaju predmeta i mogućnost utjecaja na Židovčeve političke poteze.

\section{4. Židovčeva misija u Zagrebu}

U Autobiografiji Židovec tvrdi kako je većina članova Stana zahtijevala da Nikšić intervenira protiv Vujičićevih ubojica (zacijelo u Zagrebu) i da je on to obećavao pokazujući, međutim, da mu je »to sve neugodno i teško«.18 Izgubivši strpljenje, Židovec je navodno odlučio uzeti stvar u svoje ruke te se 12. svibnja (»ako se mogu pravo sjetiti datuma«) uputio u Zagreb kako bi s predmetom upoznao ministra unutarnjih poslova Artukovića. Međutim, kako kaže, državni tajnik Stjepan Vukovac preusmjerio ga je na člana Vlade Milovana Žanića koji je svojedobno bio i stranački kolega Židovčeva oca, a šef kabineta mu je u to doba bio već spominjani A. Seitz, ${ }^{19}$ jedan od inicijalnih ustaških mentora samoga Židovca. Ljubazno primljen u Žanićevu uredu, Židovec je izdiktirao predstavku od dvanaestak stranica (za Pavelića i neke ministre) u kojoj je - kako kaže - zatražio da valjda zbog nekažnjavanja neopreznih krivaca kompromitirani Nikšić bude udaljen iz Karlovca. ${ }^{20}$

\footnotetext{
16 Slavko Goldstein, 1941. Godina koja se vraća, Zagreb, Novi Liber, 2007., str. 97-100.

17 Karaula, str.105.

18 Karaula, str. 112.

19 Bilješka o Seitzu, Hrvatska smotra, 5-6, 1941. (lipanj), str 328.

${ }^{20}$ Karaula, str. 114.
} 
No, u tom dijelu Autobiografije Židovec ne spominje da je za odlazak u Zagreb mogao imati i vlastiti karijerni razlog (neuredovanje prijekoga suda u Blagaju), a baš nigdje ni to da je Nikšić zapravo već bio u sukobu sa Željkom Kurelcem, predvodnikom skupine mladih ustaša koja je izvršila ubojstva. ${ }^{21}$

\section{Razlaz između Nikšića i Kurelca}

Naime, nakon što su 8. svibnja pronađeni leševi ubijenih, Kurelac je 10. svibnja Nikšiću podnio ostavku sljedećega sadržaja:

Karlovac, 10. V. 1941.

Gosp. predsjedniče! Vrlo mi je žao što sam došao do uvjerenja, da unatoč moje najbolje volje ne uživam više Vaše povjerenje. Držim da ukoliko bih nastavio rad pod ovakovim okolnostima, ne bi taj rad više onako harmonirao kako bi trebalo. Stoga je bolje da napustim svoj položaj ovdje, $i$ za daljni rad stavljam se na raspoloženje Ustaškom Vodstvu.

\section{Ostajem uz osobito štovanje Vaš odani Kurelac ${ }^{22}$}

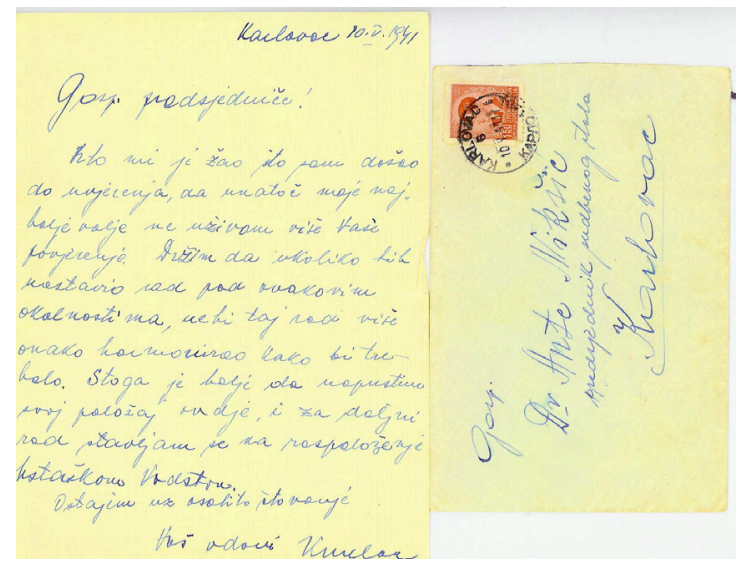

${ }^{21}$ Kurelac se kao "poručnik koji vodi borbene odrede ustaša-omladinaca« spominje u članku »Karlovac u sretnim danima hrvatskog uskrsnuća«, Novi list, 1941., 1. V, str. 16, a »ključnim čovjekom« drži ga i Goldstein, str. 81. U saslušanju 18. svibnja 1945. Kurelca je kao »glavnoga zločinca« izravno okrivio Janjaninov otac Mihajlo, umirovljeni profesor karlovačke gimnazije, ustvrdivši da su se njih dvojica sukobili još u vojsci te navevši imena svjedoka za Kurelčeve prijetnje i zapovjednu ulogu nakon 10. travnja 1941. Hrvatski državni arhiv, HR-HDA-306, Zemaljska komisija za utvrđivanje zločina okupatora i njihovih pomagača, Okružna komisija u Karlovcu, zapisnik saslušanja od 18. svibnja 1945., predmet 726/45. Milan Radeka, međutim, ne spominje Kurelca među petoricom mladića pod istragom za ubojstvo koje je susreo u zagrebačkom zatvoru. Dosje Židovec, str. 343.

22 Rukom pisan izvornik s poštanskom omotnicom s nadnevkom Karlovac 10. svibnja 1941., snimljen u obiteljskom arhivu Nikšićevih u Seattleu. Kurelac govori o »svojem položaju ovdje« što bi također upućivalo na zaključak da je imao stanovitu zapovjednu dužnost. 
Povod tom koraku morao je biti iznimno važan jer je svega nekoliko dana prije ubojstva Nikšić u već spomenutom intervjuu o razvitku ustaškoga pokreta u Karlovcu, pa i o vlastitoj preobrazbi u ustašu, Kurelca pohvalio za njegovo agilno predratno djelovanje među studentima:

》Od mladih mnogo nam je u to, sada tako daleko vrijeme, vrijedio student Žarko [sic, Željko] Kurelac, koji je osvajao đake za hrvatsku stvar. Njemu zahvaljujemo, što je ustaški pokret prodro u redove karlovačkih studenata, od kojih su se do tih dana regrutirali razni demokratski frazeri, izgubljeni u sijecanju dlake i jalovim diskusijama. $^{23}$

Pismo s ostavkom poslano je poštom u subotu i Nikšiću vjerojatno uručeno tek u ponedjeljak 12. svibnja, no dolazeći od predvodnika skupine mladih njegov sadržaj imao je i neposredne operativne posljedice te je upućenima zacijelo postao poznat praktički istoga trenutka. U opisanu kontekstu, razlaz između Nikšića i Kurelca stvarnom je voditelju poslova Stana, Židovcu, mogao pružiti priliku da - iskoristivši ga prvoga sljedećeg radnog dana - pokuša povratiti povjerenje vrha vlasti u Zagrebu, pa i da takmaca Nikšića udalji iz Karlovca.

\section{Sukob oko slučaja Vujičić}

Nasuprot tomu, Židovčeva Autobiografija ostavlja dojam da je slučaj Vujičić bio jedini problem, pa i da se njegov odlazak u Zagreb pripremao više dana. Židovec tako tvrdi:

»Kod tog Vukovca sam već prije, 2-3 puta, bio, te mu predočio citavu stvar u svoj njenoj strahoti. Vukovac se je škandalizirao i iznio mi neke vrlo zanimlivive detalje [o zagrebačkoj političkoj sceni] [...] Vukovac je pripremio moju akciju u Zagrebu i najavio me kod dr. Žanića, jer da je vidio, da će se ovaj najodlučnije zauzeti za stvar. $\aleph^{24}$

23 »z dana, kad je Hrvatska iskrsnula«, ibid.

${ }^{24}$ Karaula, str. 114. Jedino logično tumačenje izraza »strahoti« jest da se odnosi na tvrdnje o navodnoj Nikšićevoj ulozi u slučaju Vujičić prije 12. svibnja 1941. Međutim, nekoliko redaka prije Židovec kaže da je - premda su on i drugi članovi Stana otpočetka držali Nikšića »intelektualnim saučesnikom" dotičnoga zlodjela, štoviše »da tu mora biti direktno upleten « - »tek koji mjesec kasnije dobio [...] i jednu direktnu potvrdu ovakovih naših shvaćanja«, jer se navodno jedan od sudionika povjerio kako im je Nikšić bio govorio da je Vujičić »opasan za državu«. Karaula, str. 109-113. Takve vremenske nedosljednosti mogle bi značiti da Židovec u trenutku putovanja u Zagreb nije za možebitne tvrdnje o Nikšićevoj umiješanosti u ubojstvo imao nikakvih dokaza, nego ih je naknadno domislio, a možda i konstruirao u okolnostima poslijeratne istrage i zahtjeva za Nikšićevo izručenje. 
U nastavku Židovec čak precizira da je Vukovac bio uvjeren da »obzirom na bijedno držanje dr. Artukovića, nema uopće smisla s njime o tome govoriti« te da ga je odmah proslijedio Žaniću odnosno da sam Artukovića nije ni vidio. ${ }^{25}$

Međutim, iz jednoga drugog Udbina dosjea doznaje se da je Vukovac - koji se krajem lipnja 1941. povukao iz državne službe, ostao u Zagrebu i poslije rata bio pravnik u Arhivu grada ${ }^{26}$ - slučaj Vujičić spomenuo u opsežnom saslušanju 1952. Kako je tada naveo, V. Židovec donio je:

»službeni izvještaj, koji njegov otac dr. Židovec stariji šalje ministarstvu unutrašnjih poslova, na ruke dr. Artukovića. [...] koliko se mogu sjetiti prema stilizaciji koja je bila vrlo koncizna i oprezna, ipak se moglo zaključiti kao da su ti zločinci štitili interese predsjednika Okružnog suda u Karlovcu dr. Nikšića. [...] Interesi za umorstvo dr. Vujičića da bi se mogli naći u spaljivanju nekih njegovih spisa ${ }^{27}$ i u tuženju protestiranih mjenica i u nekim zapisnicima o upravljanju sokolskim društvom u Karlovcu iz kojih da se razabirala dvostruka uloga suca Nikšića, koji da je s jedne strane dobro prosperirao pod Beogradskim režimom i slao pozdravne brzojave kao sokolski funkcioner kruni i dvoru, a s druge strane se na jednom počeo isticati kao davni i najvatreniji ustaša. [...] Otišao sam skupa s dr. Židovcem smjesta do Artukovića gdje je on najprije pročitao odnosni podnesak, koji je na njega kao ministra unutrašnjih poslova bio naslovljen, a zatim saslušao izlaganje moje $i$ dr. Židovca i pravio se zaprepašten $i$ začuđen, da ti mladići još nisu pohapšeni. Vidjelo se da je o stvari već bio informiran i rekao da postupak po službenoj dužnosti vodi Ravnateljstvo za javni red i sigurnost, a on da će odmah djelovati da se krivci pospješno uhapse i protiv njih po zakonu postupa« (podcrtao B. S.). ${ }^{28}$

Kako se može uočiti, Vukovac je uvodno vrlo oprezan u svjedočenju o dopisu koji je navodno vidio prije jedanaest godina (»koliko se mogu sjetiti..., ipak..., kao da su štitili...(), ali zatim se detaljno sjeća pojedinih tvrdnji o razlozima ubojstva, kojima se Nikšić teretio tek poslije rata, i to upravo u Udbinoj istrazi 1947! Dakle, održiva je i pretpostavka da je Vukovac bio »upućen« što bi trebao potvrditi u smislu prikazivanja Artukovića kao Nikšićeva zaštitnika, pa je kontradiktornošću između nesigurno-

25 Karaula, str. 117.

26 Milan Pojić, »Vukovac, Stjepan«, Tko je tko u NDH, str. 424.

${ }^{27}$ Poslijeratna službena izjava Vujičićeve supruge isključuje palež prilikom uhićenja. HRHDA-306, Zemaljska komisija za utvrđivanje zločina okupatora i njihovih pomagača, izjava Anastazije Vujičić Okružnoj komisiji u Karlovcu od 26. lipnja 1945., predmet 726/45.

28 HR-HDA-1561, SDS RSUP SRH, 013.02.4, str. 75-76. Usp. i Goldstein, str. 85-86. 
ga uvoda i detaljnoga »sjećanja« pokušao upozoriti na svoju situaciju u trenutku davanja izjave.

Utemeljenost Vukovčeva sjećanja mogla bi se meritorno prosuditi jedino uvidom u sâm dopis F. Židovca, no ni njega nema među javno arhiviranim spisima Ministarstva unutrašnjih poslova. ${ }^{29}$ Prihvatimo li ga u dijelu o Židovčevu susretu s Artukovićem, slijedilo bi da Židovec taj susret prešućuje, a zanimljiv je i navod da je ministru slučaj Vujičić poznat i da je već u obradi nadležnoga ravnateljstva. Slično tomu, pođe li se od datacije toga susreta s 12. svibnja, dok Karlovcem još stvarno upravlja Židovec, uočiti je da su mladi zločinci još uvijek na slobodi i da dospijevaju u istražni zatvor tek u iduća dva tjedna, kad lokalna vlast prelazi u ruke navodnoga inicijatora zločina Nikšića. Slavko Goldstein spominje da ih je Kvaternikov RAVSIGUR nakon puštanja iz zagrebačkoga zatvora »rasporedio na neke dužnosti izvan Karlovca [...] da bi se nakon nekoliko tjedana opet vratili kući u Karlovac, kao da ništa nije ni bilo« ${ }^{30}$

Začudo, spomenutu svoju predstavku od 12. svibnja Židovec u Autobiografiji sažima prilično neodređeno, na način da Nikšiću pripisuje pasivnost u kažnjavanju krivaca, ali ne i odgovornost za poticanje zločina:

"Predložio [sam] sve ono što smo prije mi u ustaškom stanu tražili od Nikšića, t. j. da krivci budu privedeni zakonskoj kazni, već u interesu hrvatske stvari $i$ hrvatskog ugleda. Upozorio sam $i$ na štetne posljedice obzirom na Talijane. Upozorio sam na njihovu akciju u toj stvari (spomenuo sam kako su navodno Talijani Vujičicervu lješinu ekshumirali i fotografirali!) $i$ izrazio misljenje, da to može biti samo znak da oni spremaju neprijateljske čine spram NDH. Upozorio sam i na neoprezno držanje kako samih ubojica tako i dr. Nikšića uslijed čega je sada pred karlovačkim javnim mišljenjem teško kompromitiran i sâm dr. Nikšić. Zbog toga je potrebno, tako sam zaključio, da dr. Nikšić bude uklonjen iz Karlovca. «11

\section{Zamjena teza u udbaškoj istrazi}

Za razliku od navodna dopisa F. Židovca koji spominje Vrhovac, predstavka V. Židovca od 12. svibnja, upućena samom Paveliću i proslijeđena nekim ministrima, u porat-

${ }_{29}$ Židovec u Autobiografiji tvrdi da je Vukovcu osobno predao očevu ostavku obrazloženu Nikšićevim imenovanjem za velikoga župana, no to smješta potkraj svibnja, »ako se pravo sjećam«. Karaula, str. 121-122.

\footnotetext{
${ }^{30}$ Goldstein, str. 117.

31 Karaula, str. 114
} 
nim se spisima spominje kao dio Udbinih materijala, ${ }^{32}$ ali u Dosjeu Židovec je nema. Budući da se Židovčevo prepričavanje predstavke ne može usporediti s njezinim izvornikom, posegnuti je za još jednim mjestom u Autobiografiji, na kojemu se on poziva na svoje navodno smirujuće članke objavljene tih dana u karlovačkom tjedniku:

"Uopće nikakav teror ja u mojim člancima nisam opravdavao nego žestoko osudivao. Pošto nisam mogao govoriti otvoreno, to sam stvar iznašao u raznim aluzijama $i$ poredbama, ali brineći se kod toga da nitko ne može biti u sumnji glede toga što zapravo hoću reći. Tako sam ona oba prva clanka u karlovačkoj 'Hrvatskoj slobodi' posvetio tome kakav ustaša zapravo treba biti za razliku od toga kakove tendencije pokazuju. Clanak 'Dies irae' posvetio sam baš slučaju ubijstva dr. Vujičića i iznio tu citavo svoje ogorčenje» (podcrtao B. S.). ${ }^{33}$

Prvi od dvaju spomenutih članaka (»Jučer i danas«), pisan prije ubojstva i tiskan u prvom broju karlovačkoga tjednika, nije bio dostupan autoru ovoga teksta. Drugi članak, upravo spomenuti »Dies irae«, objavljen je šest dana nakon Kurelčeve ostavke, četiri nakon Židovčeve predstavke, i zacijelo neposredno povezan s njegovom akcijom u Zagrebu: ${ }^{34}$

»Živimo u revoluciji. Dakako, mjerilo, kojim ćemo odvagnuti sve, što se za tih dana dešava, ne može biti ono isto koje vrijedi u sređenim, mirnodopskim vremenima. Bujica dogadaja preplavila je sve nasipe i ograde. [...] To je bujica, koja je nastala kao posljedica svega onog što je bilo zlo. Elementarnom snagom provalila je $i z$ toka $u$ koji je bila skučena, $i z$ nametnutog $i$ neprirodnog toka. Posljedica je dugogodišnjih nepravda, laži prevara, pljačka i ubijanja. To su dani srdbe. To su dani suda. Bujica provaljuje $i$ ruši sve pred njom, sve što joj se ispriječi, sve što joj smeta u njenom putu. Strašni su dani srabe. No bujica valja $i$ drvlje $i$ kamenje, a u njoj ispliva kadikad $i$ smeće na površinu. A desi se, da ona pokopa $i$ udavi nešto što je lijepo. Revolucija živi po svojim zakonima, i u njoj su prema tome neizbježive razne uzgredne pojave $i$ događaji. No naša hrvatska revolucija mora biti drugačija, jer se temelji na ustaškim načelima. [...] Razumljivo, jer naša se revolucija nije podigla da se sruše osnovne ljudske vrijednosti, koje uvijek vrijede, nego da se te vrijednosti izvedu iz blata i poniženja do pune pobjede. [...] Dignute su ustaške zastave i pošlo se je u borbu tešku i dugu, u borbu krvavu i naoko bezizglednu. Pošlo se je u nju s vatrom u srcu. [...]

$32 »$ Pok. dr. Vl. Židovec je rečeni zahtjev stavio čak u pismenom memorandumu na Pavelića od 12. V. 1941., koji se također nalazi u našim spisima«. Dizdar, Ustaštvo i NDH, str. 55.

33 Židovčevo saslušanje 7. listopada 1947., prema Karaula, str. 436-437.

${ }^{34}$ Usp. Karaula, str. 120-121. 
Fer, hoće li se žrtvovati čovjek koji nema vjere? [...] Dok filistri sjede na najboljim položajima $i$ pomiruju se sa zlim oko sebe - kažu da je i onako nužno - dok uživaju sve prednosti kakove lažljive sredine, dotle nemiran duh hrabrih i idealnih boraca koji ne misle na sebe, krči krvav put boljem [...] Trebamo [...] nepokolebive, hrabre i vjerne ljude. Ne trebamo brbljavaca, koji će nepromišljeno pričati o onom o čemu se ne smije govoriti, što imade ostati tajnom « (podcrtao B. S.). ${ }^{35}$

Nasuprot Židovčevim poslijeratnim uvjeravanjima, uistinu pitijski pisani članak se po svem sudeći utemeljenije može shvatiti na način da mlade karlovačke ustaše neizravno prikazuje kao idealiste koji, uz moguća pojedina zastranjivanja, ipak naposljetku »ispravljaju« strahote prošlosti, a Nikšićev kritički odnos prema ubojstvima posredno kvalificira kao izraz malograđanskoga mentaliteta, pri čem se naročito osuđuje izjašnjavanje, dapače filistarsko brbljanje, očito javno, o nečemu što je trebalo ostati tajnom. Opravdanje nasilja nije uostalom bila neka iznimka u tadašnjem programskom profilu karlovačke Hrvatske slobode, ${ }^{36} \mathrm{u}$ čijem je uređivanju Židovec prema vlastitoj izjavi pomagao, ${ }^{37}$ a kao glavni operativac Stana zacijelo imao i jak programski utjecaj. Primjerice, tri dana prije ubojstva Vujičića i drugova objavljen je nepotpisan članak pod naslovom »Događaji u Hrvatskoj«, koji bi se također mogao promatrati u kontekstu inače prilično rastezljive kategorije »intelektualnoga začetništva《:

"Svjetovi se ruše. A kad se ruše stari svjetovi, posve je jasno, da se novi nigdje ne stvaraju preko noći i ne bez bolova. [...] Staro se je raspalo i nestaje. Nikada više ne će Hrvatska doživiti to, da bi bila gažena i robljena. Tko misli, da nije tako, tomu u Hrvatskoj nema mjesta, i za njega je najbolje, da odavle seli sam. [...] Medutim, Hrvatska ide ravno naprijed, ne obazirući se na pustolove. Na tom svom putu naprijed, ona će satrti sve, što joj bude smetalo. Zakon za zakonom niče, bolji od boljega. [...] Nestat će hiljada nepotrebnih egzistencija, sviju onih što su živili u izobilju, a nisu narodu koristili, nego samo štetovali. Taj golem i otrovan cir Hrvatska ne će uklanjati ni injekcijama ni pilulama. Uklonit će ga, kao što i treba, kirurškim zahvatom (podcrtao B. S.). ${ }^{38}$

Ako je dakle članak »Dies irae« vjerno odražavao Židovčeva uvjerenja na razini njegovih tadašnjih karijernih ambicija i u okviru prevladavajućih stajališta, ne može se olako otpisati ni poslijeratni iskaz člana karlovačkoga Ustaškog stana (i kasnijega velikog župana) Ivana Betlehema, koji je ustvrdio da mu je Židovec pri povratku

\footnotetext{
35 V. Židovec, »Dies irae«, Hrvatska sloboda, 4, 1941., 16. V, str. 1.

36 O pisanju lista usp i Goldstein, str. 153-155.

37 Karaula, str. 108.

38 »Dogadjaji u Hrvatskoj«, Hrvatska sloboda, 2, 1941., 2. V, str. 3.
} 
prvoga izvanrednoga odnosno prijekoga suda s blagajskoga uredovanja predbacio preblagi, neustaški nastup. ${ }^{39}$

Po svemu sudeći, udbaški se istražitelji poslije rata nisu bavili utemeljenošću tvrdnji o Nikšićevoj prošlosti iznesenih 1941., već su na njih samo nadogradili vlastitu tezu da je Nikšić zbog nje zaželio Vujičićev nestanak. Tako zamijenjena teza bila je u sukobu s informacijom o razlazu između Nikšića i vođe skupine mladih ustaša, vjerojatno sadržanom i u Židovčevoj predstavci od 12. svibnja, što je mogao biti dodatan razlog da ju se izuzme iz poslijeratnih istražnih spisa.

S druge strane, zacijelo zahvaljujući i uvjerljivo umjerenjačkom profilu koji si Židovec pripisuje u Autobiografiji, Betlehemov iskaz s kraja 1947. nije uzet u obzir ni u novijim povijesnim prikazima.

\section{Nametanje teze o Nikšićevu držanju u slučaju Vujičić}

Udbaška istraga, usmjerena, kako se čini, na potvrdu teze o Nikšićevoj umiješanosti u Vujičićevo ubojstvo, nije izuzela samo Židovčevu predstavku, već i jedinoga neposrednog svjedoka Židovčeve akcije u Zagrebu 12. svibnja 1941. Naime, ni u istrazi niti na suđenju Židovcu kao svjedok nije saslušan Mane Bilović, član Ustaškoga stana u Karlovcu (i kasnije tabornik), koji je, prema Židovčevim navodima, nazočio njegovim razgovorima s ministrom Žanićem i diktiranju predstavke. ${ }^{40}$ Iako je u trenutku suđenja Židovcu bio živ, na odsluženju sedmogodišnje kazne, ${ }^{41}$ taj ključni svjedok zacijelo nije bio poželjan, najvjerojatnije kako bi se spriječilo detaljnije spominjanje sadržaja Židovčeve predstavke i nastupa uopće.

Preslušan je, međutim, potencijalno važan svjedok o odnosima Vujičića i Nikšića - Milan Radeka, profesor, srpskopravoslavni kateheta, slobodni zidar, a i Vujičićev prijatelj. On o ubojstvima nije imao neposrednih saznanja jer je bio uhićen među prvima u Karlovcu (16. travnja) i deset dana poslije prebačen u zagrebački zatvor, gdje je 2. ili 3. lipnja susreo petoricu svojih đaka, ustaša, koji su tada poslani iz Karlovca u Zagreb pod istragom za zločin koji se dogodio u međuvremenu:

»Nekako su gledali u prazno. Naročito sam zapazio Šantićev ukočeni pogled uz nervozno pušenje. Svi u uniformama, razdrljenih ovratnika i bluza i košulja, lica sasvim druga, zadrigla, opaljena, podbula, kao da su od

39 Prema Betlehemovoj izjavi na saslušanju 24. listopada 1947, po povratku iz Blagaja Židovec mu je rekao: »'Vi se kolega baš niste ustaški pokazali!', a nakon toga kada sam uzvratio da bi mogao sam sebe imenovati i određivati za ovakove poslove odgovorio mi je: 'Pa da, vi bi bili za sud dobrih ljudi, a ne za izvanredni narodni sud!'. Dosje Židovec, str. 20.

\footnotetext{
40 Karaula, str. 113-114.

41 Goldstein, str. 134.
} 
nekog žderanja i lokanja izobličena. Sasvim druga lica nego ona dječačka još jedva prije mjesec dana [...] [jedan od privedenih kaže] 'Ovo je zabuna. Odmah će nas pustiti kad vide da nas kod prozivanja nema'. Oni su ipak još tu noć proveli u policiji, ali ne u ćelijama, nego u službenoj sobi, a sutradan su zaista odmah pušteni. $\aleph^{42}$

Dva mjeseca nakon što je u zagrebačkom zatvoru susreo svoje bivše đake, Radeka je s obitelji protjeran u Srbiju. Tamo je 8. kolovoza 1942. zapisnički izjavio da su »dva studenta - Aleksandar Šantić i Joco Gombač - inicirali i predvodili ubojstvo članova lokalne srpske elite kao što je bio advokat Milan Vujičić i Gojko Janjanin, kapetan pješadije. ${ }^{43}$

Međutim, u svom iskazu poratnim istražiteljima Radeka slučaj označava neobjašnjenim, pri čem u jednom retoričkom pitanju kao jednu od dviju mogućnosti nabacuje tvrdnju koju je Židovec iznio u Autobiografiji, ${ }^{44}$ i koja mu je, dakle, mogla biti sugerirana tijekom ispitivanja:

»Smrt Vujičićeva još nije objašnjena. Da li je ubijen zato da se Srbima pokaže što ih čeka od Hrvata koji ovako uzvraćaju svojem najvećem prijatelju, ili je ubijen kao advokat da bi jedan od najuglednijih karlovačkih ustaša riješio pitanje svojih meničnih dugova? «" ${ }^{45}$

Radeka je tada ustvrdio i da je Nikšić sudjelovao u izaslanstvu Jadranske straže na komemoraciji kralju Aleksandru na Oplencu na Duhove (9. lipnja) 1935. No, kako su desetljeća prolazila, Radekino sjećanje poboljšavalo se, ali donekle i mijenjalo. Početkom 1980-ih Oplenac i Jadranska straža i dalje su bili aktualni, spominjalo se i Nikšićevo oduševljenje Srbijom uoči I. svjetskoga rata, ali navodne mjenične dugove zamijenila je tvrdnja da je Nikšić na jednoj mjenici krivotvorio potpis svojega brata, o čemu da je »znao [Radekin] pašanac dr. Nikola Narančić, advokat iz Gospića, a i dr Milan Vujičić. $\ll^{46}$

U sljedećem nastavku sjećanja odgovornost se uz stanovitu ogradu pripisuje Nikšićevoj supruzi, ali navodna »afera« neodređeno je spomenuta: »Njegovoj su [Vujičićevoj] likvidaciji navodno kumovale Nikšićeva žena Ema i Šantićka, žena

42 Milan Radeka, »Neka sjećanja na 1941.«, Ljetopis Srpskog kulturnog društva »Prosvjeta«, 5, 2000., str. 44. Usp. i Goldstein, str. 116-117.

43 Navedeno prema Rory Yeomans, Visions of Annihilation, The Ustasha regime and the Cultural Politics of Fascism 1941-45, Pittsburgh, University of Pittsburgh Press, 2013., str. 52, 372.

44 Židovec, naime, piše i ovo: »Govorilo se je, da ga je dr. Vujičić pomagao na taj način, što mu je potpisivao mjenice, koje je kasnije sam morao plaćati«. Karaula, str. 110.

45 Dosje Židovec, str. 343.

46 Radeka, »Za koga kavez«, 1, Oko, 244, 1981., 23. VII-6. VIII., str. 20. 
mjesnoga fotografa. Jer Vujičić je mogao biti neugodan svjedok u nekoj aferi Nikšićevoj...«. ${ }^{47}$

U posljednjem Radekinom autobiografskom uratku, posmrtno objavljenom 2000, uz prije navedene slučajeve precizira se da su Narančić i Vujičić sudjelovali u zataškavanju krivotvorena bratova potpisa te dodaje da je Nikšić od posljednjega $\gg i$ novaca uzimao, na zajam ${ }^{48}{ }^{8}$ a dodatno se razrađuje i Emina uloga, za koju se bez ograde tvrdi da:

"udesila je da tako neugodan svjedok nestane. Sudjeluje i njezina prijateliica, žena fotografa Šantića. Šantićka je imala sina, 1938. kao odlična oproštenog od usmene mature, bistra i pametnog dečka, tamnoputa ljepotana, ali i skroz pokvarenog derana $i$ uz to sada gorljivog ustašu, a zvao se Aleksa Šantič! Taj Šantić s nekoliko drugih dječaka [...] uze Vujičića sa još par žrtava [u mesarski krvavo-crveni kamionet Gombačeva oca] [...]. Odvezoše ih u šumu iza Rečice i tamo zvjerski pobiše» (podcrtao B. S.). ${ }^{49}$

Tako se teza o Nikšićevoj osobnoj odgovornosti za Vujičićevu smrt - lansirana, čini se, od udbaških istražitelja i zatim napuštena u sudskom procesu - s vremenom prebacila na njegovu suprugu. Vrijedno je spomenuti da je Ema Nikšić imala psihičkih problema i da je brak prema obiteljskim prosudbama bio prilično nesretan te da su supružnici cijelo poratno vrijeme, sve do Nikšićeve smrti 1962., živjeli odvojeno. ${ }^{50}$ Čini se da je i Radeka bio svjestan nedoumica koje otvara njegova posljednja tvrdnja, a možda i nikšićevskih obiteljskih neprilika, pa cijeli ulomak posvećuje pomalo začudnim razmišljanjima o naravi obiteljskih odnosa:

»Na ovo se mora primijetiti kako ono pravilo da porodica ne odgovara za zločine nekoga svoga, ne može općenito vrijediti. Zna se koliko žena može djelovati u kući. A uloga Nikšićke i Šantićke u ubistvu Vujičića to i pokazuje. Primjera takvih bilo je $i$ više da je muž ženine ambicije ili histerije imao da plati glavom kao ustaša. Pa $i$ ako se uzme da nijedna žena ni majka nije mužu ili sinu rekla otvoreno: Ubijaj! - mogli su to oni osjetiti po njezinu držanju, ispadima mržnje prema političkim protivnicima, $i$ iz onog svega, konačno, što se u kućama po društvima večernjim govori $i$ pretresa o situaciji. Fer žene, kao i djeca, mogu biti svirepije nego muški..151

\footnotetext{
47 Isti, »Za koga kavez«, 2, Oko, 245, 1981., 6. VIII-20. VIII., str. 20.

48 Radeka, »Neka sjećanja na 1941.«, str. 41.

49 Ibid., str. 42.

50 Podatak iz intervjua s Nikšićevom kćerkom Dunjom von Veh, Seattle, 5. travnja 2014.

51 Radeka, »Neka sjećanja na 1941.«, str. 42.
} 
Ukratko, kako se vidi, u svojim izjašnjavanjima - za koja ne možemo isključiti da su temeljena na relevantnim saznanjima - Radeka se, dakle, djelomice uklopio u tvrdnje da je Nikšić mogao u Vujičiću vidjeti neugodnoga svjedoka, ali nije izričito podupro udbašku verziju koja je to navodila kao razlog ubojstva. Zanimljivo je ipak da je Radekina teza o Eminoj ulozi ostala potpuno nezapažena u narednim povijesnim i literarnim verzijama slučaja.

S druge strane, jedini od mladih ubojica koji se poslije rata našao pred komunističkim sudom, i to desetak mjeseci nakon presude Židovcu, bio je upravo Aleksandar Šantić. S njim je tada razgovarao jedan od vodećih udbaša karlovačkoga kraja, poslije ministar unutarnjih poslova RH Josip Boljkovac. U svojim memoarima Boljkovac se drži poratne konstrukcije Udbe o upletenosti Nikšića u Vujičićevu smrt, dodajući joj još jednu varijantu. Tvrdi, naime, da mu je Šantić 1948. rekao da je:

»Nikšić bio svjestan da Vujičić zahvaljujući bliskim vezama sa Šubašićem, zna da je on [Nikšić] bio agent jugoslavenske policije i brzom je likvidacijom želio spriječiti da se to razglasi po gradu. Šantić mi je tvrdio da u trenutku ubojstva ni on nije znao pravu istinu, ali da je poslije saznao za pozadinu toga slučaja jer je radio za Gestapo i njemačke obavještajne službe« (podcrtao B. S.) ${ }^{52}$

Tvrdi se, dakle, da je jedan od ubojica, kasnije nisko rangirani agent Gestapa, saznao tek naknadno od svojih njemačkih kolega za navodnu motivaciju onoga što je učinio. U arhivu njemačkoga policijskog atašea za NDH (danas u Hrvatskom državnom arhivu) o tomu nema ništa, iako se on povremeno bavio Nikšićem. Tamo se Nikšića u više navrata spominje negativno (a i netočno) kao masona, ${ }^{53}$ a jedan suradnik dojavljuje Nijemcima, primjerice, da je kao ministar interno kritizirao ponašanje državnoga tajnika Seitza, koji da se pred kolegama hvalisao kako je iskoristio mladu Židovku koja ga je došla moliti za intervenciju. ${ }^{54}$

U svojoj posljednjoj bilješci o Nikšiću 1957. karlovačka Udba nastavlja tragom svoje početne konstrukcije, pa bilježi da se na suđenju Šantiću 1948. Nikšića teretilo za likvidaciju Vujičića jer je pred njime kao svojim »najboljim prijateljem«:

»istupao na jugoslavenskoj liniji, naročito 1938. i 1939. g., kada se borio za položaj predsjednika Okružnog suda u Karlovcu. Zbog toga što je Vujičićo njemu vrlo mnogo znao, on ga je dao likvidirati [...] Nemamo živih svjedo-

52 Josip Boljkovac, Istina mora izaći van... Sjećanja $i$ zapisi prvog ministra unutarnjih poslova neovisne Hrvatske, Zagreb, Tehnička knjiga - Golden marketing 2009, str. 20.

53 HR-HDA-1521, Arhiv Helm, kutija 10, predmet 67, dr. Walz.

54 HR-HDA-1521, Arhiv Helm, kutija 27, predmet 39, dr. Pavao Canki. 


\section{ka, koji bi potvrdili da je Nikšić za to dao usmeno ili pismeno naređenje, ali $i z$ više podataka kao i nekih sudskih rasprava proizlazi da je tako kako je napred navedeno«..$^{55}$}

Tu, dakle, više nije riječ o nekoj tajnoj, agenturnoj Nikšićevoj suradnji s jugoslavenskom policijom, već o tvrdnji da je želio prikriti kako je pred Vujičićem potkraj 1930-ih otvoreno (!) nastupao projugoslavenski. Boljkovčevo prisjećanje zanimljivo je i stoga što pokazuje da se on navodne povezanosti Nikšića sa slučajem Vujičić ne sjeća kao nekoga eventualnog skandala iz Karlovca 1941., nego da kao visoki udbaš samo ponavlja i blago varira središnju tezu istražnoga centra u Zagrebu iz 1947.

Zaključno, u ponuđenoj dokumentaciji nema ni vjerodostojnoga izvora ni logičnoga razloga koji bi upućivali na Nikšićevu inicijativu za likvidaciju prijatelja Vujičića. Preostaju tako samo nedokumentirane uopćene tvrdnje da su omladinci bili potaknuti nečim što je Nikšić rekao, bez i najmanjega preciziranja što je, kada i u kakvom kontekstu moglo biti izrečeno. Nigdje pak nema riječi o činjenici - ovdje i formalno dokumentiranoj - da se odmah nakon počinjenoga zločina oko nečega zacijelo važnog razišao s vođom omladinaca Kurelcem.

\section{Tehnologija ocrnjivanja}

Uzimajući u obzir asimetriju političke moći 1941., udbaška je teza već polazno bila krajnje neuvjerljiva. Nakon stvaranja NDH Vujičić se našao u teškom položaju bez ikakva političkog utjecaja, a Nikšić je mogao - ako bi se našao na udaru nekih njegovih ucjena - svoju ustašku vjerodostojnost dokazati pozivom na uspješno preuzimanje vlasti te brzo razoružanje lokalnoga garnizona jugoslavenske vojske, pri čemu su važnu ulogu odigrale upravo njegove osobne veze s hrvatskim časnicima. Drugim riječima, Vujičić nije u novim okolnostima mogao predstavljati neku ugrozu za Nikšića koji se uostalom mogao pozvati i na jaku obiteljsku vezu s pravaštvom, pa i s ustaštvom u njegovoj oporbenoj fazi. Naime, istodobno s preuzimanjem vlasti 10. travnja 1941. u Karlovcu, slične su operacije predvodili njegov brat Marijan ${ }^{56} \mathrm{u}$ Šibeniku te nećak dr. Krsto Trgovčevićs7 u Jastrebarskom.

Umjesto dokaza ili uvjerljivih indicija o Nikšićevoj umiješanosti u ubojstvo Vujičića i drugova, Židovec je u svoju Autobiografiju uvrstio niz negativnih osobnih opisa. Kako je već naznačeno, Nikšića opetovano spominje kao ograničenoga i nesposobnoga karijerista, spremnoga na bilo kakvu amoralnu radnju, pa se njegova

${ }^{55}$ HR-HDA-1561, SDS RSUP SRH, kutija 89, Personalni dosje br. 300112 - Ivan Betlehem. Usp. Goldstein, str. 81, 132.

${ }^{56}$ Usp. Aleksandar Vojinović, »Nikšić, Marijan«, Tko je tko u NDH, str. 296-297.

57 Usp. Mate Rupić, »Trgovčević, Krsto«, ibid., str. 405. 
odgovornost za smrt Vujičića razumije sama po sebi te se zapravo i ne treba posebno dokazivati. Nikšić se tako na raznim mjestima opisuje kao:

"glup i prilično ograničen [...] beskarakteran i ambiciozan karijerista i laktaš [...] prilično nesolidan [...] sa stručnim pravnim znanjem ispod prosjeka $i$ ispod minimuma [...] neinteligentan $i$ šuplii frazer [...] neznalica [...] karakterno nesolidan i nesiguran [...] apsolutno radno nesposoban i osoba cijji su dometi pametnom čovjeku jasni za pet minuta«.58

Međutim, sva ta navodna ograničenja nisu Nikšića spriječila da, primjerice, tijekom studija bude biran na odgovorne funkcije u studentskim organizacijama, dobije povjerenje akademika Bazale da mu vodi izbornu kampanju prilikom angažiranja u politici 1925. te da održava prijateljske odnose s poznatim intelektualcima i javnim radnicima.

Udbaški pseudonim Dizdar (dakle, vjerojatno sâm Židovec) pokušao je enigmu Nikšićeve osobnosti razjasniti u tekstu Politički portreti, pisanom nakon istrage i suđenja, u kojemu Nikšića karakterizira kao socijalno kompetentnu osobu, pa ispada da je riječ o krajnje podvojenoj osobnosti:

"Dr. Nikšić [je] imao laskav i vrlo okretan način saobraćaja s ljudima, tako da se znao snaći u svim sredinama, $i z v r s n o$ prikriti prave nakane $i$ učiniti se ljubaznim i srdačnim. Na taj način u pravilu mu je uspijevalo da obmane ljude s kojima je dolazio u doticaj. Oslanjao se na one, koji imadu novac ili vlast, ali nije zanemarivao nikoga - očito mu je životna deviza bila: 'Rijetki ti mogu pomoći, ali najneznatniji čovjek može ti naškoditi!'«"59

U karlovačkom dijelu Židovčeve Autobiografije nema, međutim, mjesta bilo kakvom relativiziranju čovjeka kojega je doživljavao kao takmaca u borbi za vlast. Tako se primjerice Nikšićeva najava pri povratku iz Zagreba da će se u cijeloj zemlji izvršne funkcije vlasti iz lokalnih ustaških tijela vratiti u državne institucije tumači njegovom osobnom pakošću s namjerom razvlaštenja lokalnoga Ustaškoga stana (kojim inače barem formalno predsjeda). ${ }^{60}$

Nikšiću se uopćeno pripisuju vrlo ružne izjave, a zatim se s njima slobodno manipulira. Pritom se u karakternom blaćenju znadu potkrasti zanimljive semantičke nijanse. Primjerice, Židovec je za nj u Autobiografiji rekao da se upravo »onih prvih dana odnosno tjedana NDH [...] iz Zagreba [vratio] očito vrlo zadovoljan i u raz-

58 Dosje Židovec, str. 24, 27, 32, 120, 127, 152.

59 HR-HDA-1561, SDS RSUP SRH 013.1.3 Dizdar, Politički portreti, str. 20.

${ }^{60}$ Karaula, str. 102. Upravne i izvršne ovlasti ustaških povjerenika i stanova prenesene su u nadležnost državnih tijela Pavelićevom odredbom od 20. travnja 1941. »Odredba poglavnika dra Ante Pavelića svim ustaškim povjerenicima i ustaškim stanovima«, Hrvatski narod, 76, 1941., 29. IV, str. 1. 
govoru s nama izbacio i ovo: 'U našoj revoluciji mi ćemo do koljena gaziti u krvil'« (podcrtao B. S. ${ }^{61} \mathrm{Na}$ drugom mjestu u Dosjeu ta se izjava spominje čak i kao Nikšićeva vlastita »teza«. ${ }^{62}$ Nakon istrage i osude Židovca, u Dizdarevoj studiji o ustaštvu ta se strašna sintagma, međutim, pojavljuje u osjetno drukčijem kontekstu - umjesto velikoga zadovoljstva tu je riječ o opravdavanju. Tvrdi se, naime, da se Nikšić »opravdavao: 'Rečeno mi je na najvišem mjestu, da ćemo mi u našoj revoluciji gaziti do koljena u krvil'« (podcrtao B.S.). ${ }^{63}$ Sâm se izričaj dakle pripisuje zagrebačkom ustaškom vodstvu, a Nikšić se opravdava da prenosi tuđe izjave.

Također, slika u kojoj se Nikšić nadaje kao idejni začetnik ubojstva u Dosjeu se osnažuje tvrdnjom o njegovoj dominaciji nad grupom ubojica. Židovec se tako sjeća da je:

»čitavu aferu pogoršavala okolnost što su se oni mladići za koje je čitav grad znao da su ubojice, osjećajući se sigurnima pod moćnom Nikšićevom zaštitom, ponašali drsko i izazovno. K tome su još bili toliko neoprezni pa su se svagdje pokazivali da su u direktnoj Nikšićevoj službi, tako da se je svima morao nametnuti zaključak da to umorstvo nisu izvršili ti mladići sami, nego direktno po uputama Nikšićevim, ili, u najmanju ruku, uz njegovo intelektualno saučešće. Bio sam jednom prilikom prisutan kad je provalio u Veliku kavanu u Karlovcu Augustinović i tamo pred svima vikao na zakupnika benzinske stanice, da mu imade odmah izdati benzin - po nalogu pretsjednika Nikšića! ${ }^{64}$

Pitanje kontrole nad skupinom mladih ustaša bilo je nesumnjivo za Židovca posebno osjetljivo zbog njihove povezanosti s Ustaškim stanom kojim je upravljao. Ipak, kao jedini primjer posebnoga Nikšićeva utjecaja navodi se prepotentno ponašanje i pozivanje na viši autoritet jednoga mladića o kojemu se drugdje u spisu može saznati da je bio neposredno podređen Židovcu - pred njim je položio ustašku zakletvu, Židovec ga je operativno vodio tijekom ilegalnoga djelovanja u Jugoslaviji, Židovčeva ga tajnica na suđenju spominje kao čovjeka koji mu je zalazio u odvjetničku kancelariju i Židovec ga dan nakon što je sudjelovao u Vujičićevu ubojstvu zadužuje da autom prikuplja članove prijekoga suda za Hrvatski Blagaj koje je upravo imenovao. ${ }^{65}$

\footnotetext{
61 Karaula, str. 106.

62 Ibid., str. 271.

${ }^{63}$ HR-HDA-1561, SDS RSUP SRH, 013.0.3 Dizdar, Ustaštvo i NDH, str. 55.

${ }^{64}$ Karaula, str. 112.

${ }^{65}$ Dosje Židovec, str. 12-13, 345, 338-339.
} 


\section{Nepouzdanost »dokaza«}

Jedan od primjera koji upozoravaju na nepouzdanost »dokaza« u slučaju Vujičić jest navodno spaljivanje dokumenata za koje se tvrdi da se dogodilo prilikom odvjetnikova uhićenja. Tako primjerice Goldstein spominje palež, tumačeći ga kao uništavanje materijalne evidencije štetne za Nikšića, što je vjerojatno preuzeo iz spomenuta Vukovčeva sjećanja na sličan navod u nestalom podnesku F. Židovca ministru Artukoviću. No, kako je već spomenuto, Vujičićeva udovica Anastazija izjavila je u poraću Okružnoj komisiji za utvrđivanje zločina okupatora i njihovih pomagača da taj odnosno »ovaj put nijesu počinili nikakove pljačke ${ }^{66}{ }^{66}$ Ako je bilo pljačke, koja bi dakako mogla uključiti i otuđenje odnosno spaljivanje dokumenata, do toga je moralo doći drugom prilikom, vjerojatno nakon što je Vujičić odveden. ${ }^{67}$

Da je cilj Vujičićeva uhićenja bio da se nađu i unište neki dokazi vezani uz Nikšićeve osobne interese - prije svega, kako se tvrdi, neke mjenice - mlade bi se zločince moralo unaprijed obavijestiti o naravi onoga što treba tražiti. No, u Šantićevoj naknadnoj izjavi takav se postupak ne spominje, a bio bi i kontraproduktivan za Nikšića jer bi proširio krug ljudi upoznatih s onim što bi on eventualno želio prikriti.

Kao što je već spomenuto, u Vukovčevoj izjavi Udbi iz 1952. prepričava se, s puno opreza, predstavka F. Židovca ministru Artukoviću u kojoj se navodno tvrdilo da je Nikšić u prethodnoj državi bio angažiran u Jugosokolu te da je »slao pozdravne brzojave kao sokolski funkcioner kruni i dvoru«. V. Židovec služi se sličnim tvrdnjama u članku »Dva svijeta«, objavljenom u ljeto 1942. u Oršanićevu časopisu Hrvatska smotra, aluzivno pišući o neimenovanom Nikšiću kao prototipu »nastaše«, karijerista koji se "grlato namiću i ništa ih ne smeta, primjerice, ako su još jučer putovali u Oplenac i vlastoručno pisali kao tajnici Jugosokola zapisnike tog društva $\kappa^{68} \mathrm{U}$ poratnoj Autobiografiji Židovec tvrdi da je Nikšić bio član Jugosokola, a njegov obavještajni alias Dizdar precizira da je u »zloglasnom Jugosokolu [...] za svaki slučaj još početkom 1941. platio članarinu sve do kraja godine«. Profesor Radeka, kojemu je u ustaškom zatvoru sudrug bio »profesor Marko Sabljić, jugoslavenski orijentirani starješina Sokolske župe Karlovac«, ni u svom poratnom iskazu Udbi ni u objavljenim sjećanjima ne spominje Nikšića među Hrvatima članovima Jugosokola. Radeka, međutim, tvr-

66 Hrvatski državni arhiv, HR-HDA-306, Zemaljska komisija za utvrđivanje zločina okupatora i njihovih pomagača, izjava Anastazije Vujičić Okružnoj komisiji u Karlovcu 26. lipnja 1945., predmet $726 / 45$.

67 Vujičić je, prema Radeki, u danima prije odvođenja supruzi povjerio slutnju da će »samo nestati«, iz čega se može zaključiti da je odveden bez nekih prethodnih najava ili upada. To upućuje na zaključak da se udovičina poratna naznaka »ovaj put« odnosi na neku pljačku nakon, ne prije Vujičićeva odvođenja. Dosje Židovec, str. 343.

68 »Dva svijeta«, Hrvatska smotra, 7-8, 1942., srpanj-kolovoz, str. 174. 
di da je Nikšić bio djelatan u Jadranskoj straži te da je išao na Oplenac kao član glavnoga odbora te organizacije. ${ }^{69}$

Kad na izvorištu gotovo svih tih tvrdnji i ne bi bio sam Židovec, pripisivanje navodnoga odlaska na Oplenac sad Jugoslavenskom sokolu sad Jadranskoj straži daje naslutiti da se moglo raditi o ponavljanju glasina o javnim osobama kakvima oduvijek obiluje hrvatska politička scena. ${ }^{70}$ Premda je nakon toliko vremena teško dokumentirati da Nikšić - od malenih nogu angažiran član Hrvatskoga sokola - nije bio član i još neke organizacije, moguće je da se radilo o zamjeni identiteta. Naime, jedan od vodećih karlovačkih jugosokolaša bio je Josip Nikšić, ravnatelj Učiteljske škole. ${ }^{71}$ Također, neki Adolf Nikšić bio je kao tajnik mjesnoga odbora zagrebačke Jadranske straže aktivno uključen u komemoriranje kralja Aleksandra pohodom Oblasnoga odbora na Oplenac 16. lipnja 1935.72

Književnik Stjepan Mihalić, prvi urednik obnovljene serije karlovačkoga tjednika Hrvatska sloboda, koji je 1941. usko surađivao sa Židovcem, poslije rata prisjećao se u Nikšićevu slučaju samo da mu je ime bilo na nekoj listi priloga za oplenačku komemoraciju $1935 .{ }^{73}$ Ta se mogućnost naravno ne može isključiti - u uvjetima monarhističke diktature državni su službenici bili praktički prisiljeni sudjelovati u takvim sabirnim akcijama.

Ukratko, insinuacije protiv Nikšića kao relativnoga novodošljaka u karlovačku sredinu mogle su se temeljiti na zamjeni identiteta koja se potiho širila u lokalnom nacionalističkom krugu, a da nitko nije imao petlje iznijeti sumnje i zatražiti da se utvrdi istina. Zabrinjavajuće je u tom slučaju što je tvrdnje o članstvu u Jadranskoj straži poslije rata iznosio i Radeka koji je zasigurno bolje od hrvatskih nacionalista poznavao projugoslavenske organizacije o kojima je riječ, no koji - koliko je poznato - nije i sam bio njezin član. No, u cijeloj priči o Nikšićevu članstvu u jugoslavenskim prorežimskim organizacijama najčudnija je temeljna poratna udbaška postavka da

69 Dosje Židovec, str. 341; Radeka, »Za koga kavez«, ibid. Usp. bilj. 46.

70 Inače, Nikšićeva kćerka Dunja von Veh (intervju u Seattleu, 4-5. travnja 2014) i nećak Nikola Nikšić (intervju u Buenos Airesu, 25. ožujka 2015) odlučno isključuju mogućnost članstva ili bilo kakvog angažmana Ante Nikšića u Jugosokolu ili Jadranskoj straži.

71 U broju od 29. listopada 1931., dakle usred najžešće monarhističke diktature, ljubljanski Sokolski glasnik - glasilo Saveza Sokola Kraljevine Jugoslavije, objavio je preko cijele prve stranice članak Josipa Nikšića iz Karlovca »28. i 29. oktobra 1918. - povodom dana oslobođenja čehoslovačkog i našeg naroda«. Prema Bibliografskom katalogu Leksikografskoga zavoda Miroslav Krleža, Josip Nikšić slično je intonirane članke o sokolstvu objavljivao i u periodicima Soko na fadranu (1932), Sokolski vjesnik župe Karlovac (1933) i Čuvajmo fugoslaviju (1934., 1936-38).

72 Državni arhiv u Zagrebu, HR-DAZG-795, Jadranska straža, Oblasni odbor Zagreb, zapisnik 11. oktobra 1934.

${ }^{73}$ Podatak zabilježen u intervjuu 3. prosinca 2015. s Radovanom Radovinovićem, svojedobnim direktorom Historijskoga arhiva u Karlovcu. 
bi takvo njegovo navodno javno djelovanje moglo biti spojivo s istodobnim obnašanjem vodećih funkcija u tajnim nacionalističkim strukturama te da bi se poslije prevrata 1941. mogle zanijekati fizičkim uklanjanjem Vujičića.

\section{Fama o britanskom "papiru»}

U Židovčevoj Autobiografiji Nikšić se pojavljuje i u jednom od autorovih najtraumatičnijih iskustava, neuspjelom pokušaju poratnoga odlaska u Argentinu. Slučaj nije povezan s Vujičićevom kobi, ali u Dosjeu služi da osnaži opis Nikšića kao amoralnoga nitkova i Židovčeva sudbinskoga zloduha. Naime, kad se Židovec 4. ožujka 1947. s obitelji trebao iz đenovske luke brodom uputiti u Argentinu, zajedno s petnaestak drugih izbjeglica uhićen je u raciji britanskih obavještajaca. Istom prigodom obavještajci su Nikšića propustili nakon što im je navodno "pokazao neki papir«. Prema Židovcu, u prvim danima NDH njemačke su postrojbe u Karlovcu zatekle i britanskoga konzula iz Ljubljane Leonarda C. Pettitta, koji se pokušavao dokopati jadranske obale. On mu je navodno pritom nastojao pomoći, a Nikšić je bio za to da ga se prepusti Nijemcima. Ipak, nastavlja Židovec, prenoseći informaciju koju je navodno čuo u rimskom zatvoru:

"Dr. Nikšić, - vidi se, oprezan čovjek! - da si je dao prigodom odlaska tog Engleza iz Karlovca od njega izdati potvrdu da ga je on, dr. Nikšić, spasio i propustio! Tu potvrdu da je dr. Nikšić pokazao onog dana (4. 3. 1947.) u Genovi majoru Clissoldu, kad je ovaj vršio hapšenja prije ukrcavanja na brod. To da je bio jedan od važnih razloga zbog kojih Clissold nije uhapsio $i$ Nikšića, nego ga je propustio da ode u Ameriku! « ${ }^{74}$

Iz njemačkih obavještajnih materijala poznato je, međutim, da je Pettitt definitivno zaustavljen u Karlovcu i odanle poslan u Graz i internaciju. ${ }^{75}$ No, ako se nije »izvukao«, kakav je to papir onda Nikšić mogao pokazati Clissoldu? Iz obiteljskoga kruga Nikšićevih moglo se saznati da je Ante, za razliku od ostalih putnika, na brod došao s talijanskom putovnicom, kartom kupljenom neuobičajenim kanalom i uvježbanom, pomalo grotesknom pričom o sebi kao nezakonitom, vrlo religioznom djetetu jednoga grofa, a uz to i sklonom istom spolu. ${ }^{76}$ Clissold je »Novaka« propustio bez većih teškoća, a zadržane putnike, među njima Židovca, dao izručiti Jugoslaviji.

Slučaj je, međutim, još jedan poučan primjer kako se nakon slabe provjere i brzopletih zaključaka znadu izmiješati stvarni događaji i proizvoljne tvrdnje. Naime,

74 Karaula, str. 108. Usp. Goldstein, str. 131-132.

75 Hrvatski državni arhiv, HDA-1521, Arhiv Helm Hans, kutija 16, predmet 34, dr. Stanislav Lapayne.

${ }^{76}$ Intervju s Nikolom Nikšićem, Buenos Aires 25. ožujka 2015. 
prema informacijama iz obiteljskoga kruga, doista je postojao jedan dokument na britanskom diplomatskom memorandumu, ali se nije ticao Ante već njegova brata Marijana. Njime se tadašnji šef britanske ekonomske misije u Ateni, a predratni generalni konzul u Zagrebu, Thomas C. Rapp, poslije rata odužio Marijanu Nikšiću, koji je kao šef policije i čelna osoba nove vlasti u Šibeniku 10. travnja 1941, koordinirao ustaške aktivnosti i u zaleđu grada. Kad mu je iz Drniša telefonski dojavljeno da je Rapp zaustavljen, naložio je tamošnjim ustašama da britanskom diplomatu omoguće nastavak puta prema Splitu. Tamo je bio uhićen od Talijana i odveden u dvogodišnju njemačku internaciju. Poslije pet godina - i pola godine prije racije u genovskoj luci - u jednom se pismu na službenom memorandumu više nego uljudno zahvalio Marijanu Nikšiću i ponudio mu pomoć u poratnim prilikama:

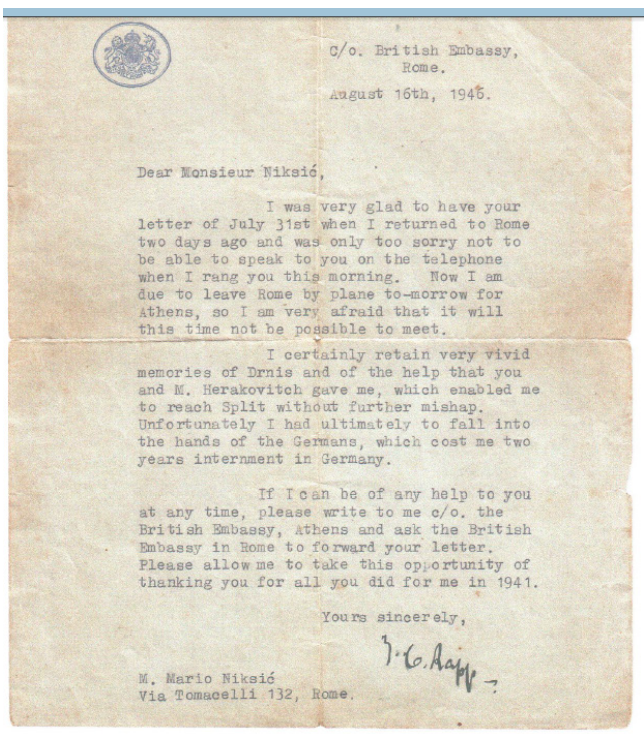

clo Britansko veleposlanstvo

Rim 16. kolovoza 1946.

Poštovani monsieur Niksic,

Bilo mi je jako drago primiti Vaše pismo od 31. srpnja kada sam se prije dva dana vratio u Rim $i$ baš mi je bilo žao da nisam bio u mogućnosti da s Vama razgovaram preko telefona kada sam Vam se javio ovoga jutra. Sada mi predstoji odlazak zrakoplovom iz Rima za Atenu pa se bojim da ovoga puta neće biti moguće da se susretnemo.

Fa se doista živo sjećam Drniša i pomoći koju ste mi pružili Vi $i$ g. Herakovitch $i$ koja mi je omogućila da dođem do Splita bez daljnjih problema. Bilo mi je na žalost sudeno da padnem u ruke Nijemaca, što me je koštalo dvije godine zatočeništva u Njemačkoj.

Ako Vam bilo kada mogu biti od bilo kakve pomoći, molim Vas da mi pišete clo Britansko veleposlanstvo Atena $i$ zatražite britansko veleposlanstvo u Rimu da proslijedi Vaše pismo. Dozvolite mi da iskoristim ovu priliku da Vam zahvalim za sve što ste učinili za mene 1941. $\mathrm{g}$.

\section{Iskreno Vaš T. C. Rapp ${ }^{77}$}

77 Prijevod s engleskoga izvornika iz obiteljskoga arhiva Nikšić u Buenos Airesu (danas u posjedu B. S.). Pismo je naslovljeno »g. Mario Niksic, Via Tomacelli 132, Rim«, što je adresa Zavoda sv. Jeronima. 
Zahvala britanskoga diplomata, koji je upravo u to vrijeme imenovan ambasadorom u Meksiku, da bi 1950. postao šefom britanskoga Ureda za Bliski istok u Kairu, bila je dakle dana naknadno, u punoj slobodi, i pomogla je Marijanu Nikšiću da posve legalno dođe u Argentinu. Jedina je poveznica Clissolda s tim slučajem što je 1938-41. bio na odgovornoj funkciji u Rappovu generalnom konzulatu u Zagrebu, tada jednom od ključnih britanskih obavještajnih i diverzantskih centara s djelatnostima $u$ sjevernom dijelu Jugoslavije te prema Italiji i Njemačkoj. ${ }^{78}$ Nema, međutim, indicija da mu je u trenutku racije u Genovi bio poznat Rappov drniški intermezzo s Marijanom Nikšićem.

\section{2. Širi okvir Nikšićeva djelovanja}

Iz današnje se perspektive Nikšićev razlaz s mladim zločincima naravno ne može ocijeniti adekvatnom reakcijom. $U$ tadašnjim prilikama mogao je to zacijelo biti način distanciranja koji je ostavio prostora za nastavak vlastite karijere u državi za koju se zauzimao. Ne ulazeći u pitanje razine njegove opće političke odgovornosti kao dužnosnika za nedjela počinjena u NDH, nameće se pitanje - bi li takvo njegovo distanciranje bila iznimka ili se uklapa u grube obrise dosadašnjih saznanja o njegovom djelovanju tijekom rata?

Primjerice, Goldstein spominje da se ustaški logornik u Slunju, Nikšićev prezimenjak Ivan, u svom pokušaju da početkom kolovoza 1941. spriječi lokalno krvoproliće nad Srbima, obratio tadašnjem karlovačkom županu (tj. Anti Nikšiću), koji je »isto intervenirao u Zagrebu, ali bez rezultata «. ${ }^{79}$

U jednom poratnom dnevničkom zapisu, datiranom sa 6. siječnja 1947., Nikšić spominje da je u dopisu Vladi NDH u kolovozu 1941. istaknuo, a u listopadu 1942. i otvoreno izjavio da se »onaj pogubni građ[anski]. rat u Hrvatskoj ne bi nikada mogao razviti da je bio dozvoljen rad Seli[ačkoj]. Stranci«. ${ }^{80}$

78 Naime, konzul Rapp nije vjerovao da će Jugoslavija moći održati neutralnost te se i osobno uključio u operacije obavještajnih službi: »Clissold je vodio promidžbenu kampanju u korist Saveznika i protiv njemačkoga utjecaja i institucija a [...] oružje je u konzulat dotjecalo i odanle se distribuiralo u takvu obujmu da je po opisu jednog svjedoka konzulat doslovce spavao na eksplozivima i detonatorima. Agenti su redovno putovali uzduž i poprijeko a pokazatelji uspješnosti su bili zavidni. Konzulat je osigurao krov nad glavom i ovećoj mreži vojnih obavještajaca, pod vodstvom budućeg šefa MI 6 (ISLD) u Kairu, James B. Millara.« Jerca Vodušek Starič, »The Concurrence of Allied and Yugoslav Intelligence Aims and Activities«, The fournal of Intelligence History, 1, 2005., str. 29-44.

79 Goldstein, str. 312.

80 Izvornik u obiteljskom arhivu Nikšić, Buenos Aires, danas u posjedu B. S. Mogla bi biti riječ o nastupnom izlaganju na sastanku vlade 27. listopada 1942. 
Prema izjavi zarobljenoga velikog župana Betlehema OZNA-i 1944., upravo je na inzistiranje Nikšića malo nakon uspostave NDH bila organizirana i »skupština HSS-a, na kojoj HSS kompletno (osim nekih iznimaka) ulazi u ustaški pokret. [...] Iza te skupštine ustaški pokret u Karlovcu i najbližoj okolici je dosegao broj od 2860 članova $\ll^{81}$

Potkraj travnja 1942. Nikšić je imenovan generalnim konzulom u Beogradu. Želeći smiriti sukobe u Hrvatskoj i osigurati vojni opskrbni kanal prema Grčkoj, tamošnje njemačko vojno zapovjedništvo za Balkan (dobrim dijelom Austrijanci) počelo ga je zagovarati kao čovjeka koji bi to mogao ostvariti. Tako je 10. listopada 1942., nakon smjene Eugena Dide Kvaternika, Nikšić imenovan ministrom unutarnjih poslova. Već na prvoj radnoj sjednici Vlade došao je u oštar sukob s Pavelićem. ${ }^{82}$

Od samoga stupanja na dužnost, dakle nekoliko mjeseci prije staljingradskoga obrata, Nikšić se ondje angažirao u pokušaju da se u Vladu uključe neka poznata imena HSS-a. David Sinčić, koji je slovio kao HSS-ov kandidat za dužnost ministra unutarnjih poslova (jedan od uvjeta), svjedočio je u udbaškoj istrazi 1949. da su se Nikšićevu posredništvu prema HSS-u u ustaškim redovima oštro protivili Vjekoslav Vrančić i drugi iz tadašnjega kruga Mladena Lorkovića. Vrančić je vodećim haesesovcima tvrdio da baš Nikšićev angažman u razgovorima može Pavelića odvratiti od nauma jer su:

"poznate izjave Nikšića o Paveliću. Najnesretnije u cijeloj stvari da je to što je baš Nikšić, kao čovjek koga je Pavelić imenovao ministrom silom prilika $i$ radi Nijemaca $i$ koga on drži iz nužde $i$ dok se potpuno u Berlinu ne raskrinka uloga Nijemaca koji su protiv NDH, što je baš on poveo razgovor s HSS i toliko se zainteresirao za sporazum s HSS-om [...] [Vrančić je] zamolio u interesu uspjeha stvari da HSS ništa ne čini što bi izazvalo neporjerenje Pavelića a i onih Nijemaca koji sve znače u Njemačkoj i o kojima jedinim ovisi sudbina $i$ citave Evrope, a to su nacionalsocijalisti a nikako Wehrmacht u kojem ima svakakvih elemenata $i$ zakulisnih namjera ${ }^{83}$

81 Milan Bekić, Ivo Butković i Slavko Goldstein, Okrug Karlovac 1941., Zagreb, Institut za historiju radničkog pokreta Hrvatske, 1965., str. 48.

82 U dnevničkom zapisu 27. listopada 1948. Nikšić navodi da je na »moje izvješće [Pavelić] reagirao onako ludo i nervozno«. U obiteljskom krugu Nikšić se prisjećao kako su mu neki kolege ministri poslije povjerili da su nakon tog sukoba očekivali da će biti uhićen. Obiteljski arhiv Nikšić, Buenos Aires (danas u posjedu B. S.).

${ }^{83}$ HR-HDA-1561, SDS RSUP SRH, kutija 10, 010.6 David Sinčić, Djelovanje HSS-a u II. svjetskom ratu, str. 28. 
Sinčić, tada veliki župan u Gospiću, prepričava i razgovor s Nikšićem početkom prosinca 1942, kada mu je ovaj rekao:

»da je razgovarao sa [Augustom] Košutićem i da su se, kako se on nadao, stvari mogle povoljno razviti prije dva mjeseca. On da je tad našao razumijevanje kod Košutića koji da je bio pripravan da se sastavi koncentraciona vlada čak i prve garniture kad bi Ministarstvo unutarnjih poslova dobila HSS, a u slučaju da je to za sada nemoguće da bi se napravila koncentraciona vlada s manje istaknutim pristašama HSS-a. Nikšić je bio do nedavna uvjeren u uspjeh, te da je i Pavelić prihvaćao njegove prijedloge, pa tako maknuo i jednog Didu Kvaternika, a da je stvar kod Nijemaca dobro stajala $i$ da se radilo o tom da odlete Pavelić $i$ Kasche. Sada ali da je on (Nikšić) nemoćan i da je više jedna obična figura, a sve zato što je Kasche uspio za sebe i Pavelića u Berlinu sa svojom tezom pobijediti. Foš da ima nada, jer da i Himmler negativno gleda na Pavelića, ali da je on u iščkivanju razvitka spora izmedu te dvije oprečne struje medu Nijemcima, a o tom sporu da sve ovisi. $1^{84}$

Nikšić se dakle od prvih ministarskih dana pojavljuje među onima koji žele promjenu smjera politike u NDH i zalažu za drukčiju politiku spram Srba. Udbaški analitičar Dizdar spominje da se ta vlada »volila nazivati 'vladom reda i zakonitosti' [...] a ministar unutrašnjih poslova dr. Nikšić, u svom osječkom govoru (početak 1943) javno govori o likvidiranju revolucionarne periode i uvažavanju stroge zakonitosti « ${ }^{85}$ Naravno, takve se izjave u uvjetima diktature i građanskoga rata mogu shvatiti jedino kao čiste govorničke figure, a u Nikšićevu slučaju i kao naznaka teško ostvarivih političkih priželjkivanja da se HSS uključi u političke procese.

Ubrzo nakon osječkoga govora, 20. siječnja 1943, Nikšić podnosi ostavku koja nije prihvaćena niti se spominje u javno dostupnoj dokumentaciji, ${ }^{86}$ a četiri mjeseca poslije imenovan je za poslanika u Rimu. Svega dva mjeseca nakon njegova nastupa na dužnost talijanski je fašistički režim svrgnut pa je ostatak vremena do sloma $\mathrm{NDH}$ proveo u Ministarstvu vanjskih poslova.

Ništa u dosadašnjim saznanjima o Nikšićevoj političkoj karijeri u NDH ne daje naslutiti da je osjećao potrebu da unutar zadanih režimskih okvira prikriva svoj kritički odnos spram vođene politike.

84 O tom i drugim razgovorima Nikšića i Sinčića, ibid., str. 24-30.

85 Dizdar, Ustaštvo i NDH, str. 124.

86 Zapis o dvogodišnjici ostavke u Nikšićevu osobnom dnevniku 20. siječnja 1945, obiteljski arhiv Nikšić, Seattle. 


\section{Slučaj Vujičić u literaturi}

Institut za historiju radničkog pokreta Hrvatske objavio je 1965. knjigu o početcima partizanskoga pokreta u karlovačkom kraju. U svom prilogu, pisanom dok Dosje Židovec nije bio javno dostupan, ali su autori s obzirom na poluslužbeni karakter studije možda mogli imati pristup nekim Udbinim bilješkama, Goldstein spominje da:

use u gradu znalo da je dan ranije po ličnom Nikšićevu naređenju Vujičić krenuo za Zagreb u pratnji trojice ustaških omladinaca - Šantića, Augustinovića $i$ Gombača. Bilo je dakle sasvim jasno tko je izvršio zločin i tho iza njega stoji ${ }^{87}$

Taj je opis Vujičićeva odvođenja kasnije napušten. Kako je već rečeno, u Radekinim sjećanjima objavljenima 1982. i 2000. iznosi se teza da je ubojstvo inicirala Nikšićeva supruga Ema s pomoću prijateljice čiji je sin (Šantić) bio jedan od ubojica. U literaturi o slučaju Vujičić koja je potom slijedila spominju se različite Radekine tvrdnje, ali ne i ta. Vrsna poznavateljica diplomatskoga djelovanja Židovca kao prvoga poslanika $\mathrm{NDH}$ u Sofiji, Nada Kisić Kolanović, imala je u radu na svojoj »Skici za biografiju V. Židovca« kao prilogu ovdje već citirane knjige izdane $2003 .{ }^{88}$ uvid u njegov dosje u Hrvatskom državnom arhivu, no Židovčev sukob s Nikšićem bio je izvan fokusa njezine studije pa nije ni posebice istraživala do koje se mjere njegova ponuđena i prihvaćena suradnja s istražiteljima odrazila na vjerodostojnost Autobiografije u karlovačkom segmentu.

Godine 2007. objavljena je ovdje također već spominjana knjiga Slavka Goldsteina 1941. godina koja se vraća, u kojoj se među ostalim opisuju prilike u Karlovcu, viđene očima djeteta koje u najosjetljivijoj dobi gubi oca i proživljava tešku tragediju svoje vjerske i kulturološke skupine. U svoja sjećanja Goldstein unosi i letimična mlada iskustva s nekima od poznatijih ljudi lokalne ustaške vlasti. Nije, međutim, osobno susreo ni Nikšića ni Židovca, pa o njima u velikoj mjeri piše na osnovu Židovčeve Autobiografije.

Njezin svojevrsni lajtmotiv - Nikšićeva krivnja i niske pobude koje mu se pripisuju - čini okosnicu Goldsteinove sugestivne literarne obrade samoga ubojstva. Autor je upravo u drami oko Vujičića i drugova prepoznao arhetip zla koji navodno povezuje NDH i današnju Republiku Hrvatsku, naslovivši opsežno poglavlje »'Afera Vujičić’ i korijeni zla«. U tako uopćenom tumačenju slučaj Vujičić je prerastao u nešto šire i odioznije od lokalnoga zločina. ${ }^{89}$

\footnotetext{
87 Bekić i dr., Okrug Karlovac 1941., str. 36, 47.

88 Kisić Kolanović, str. 267.

89 Goldstein, str. 75-134.
} 
Mjestimice gotovo doslovce prenoseći prikaze iz Židovčeve Autobiografije Goldstein je vjerojatno nehotice pridonio njezinu legitimiranju kao vjerodostojnom povijesnom izvoru. Navodi su doduše najčešće preneseni u suzdržanim kondicionalima, no njihovim kumuliranjem, pa i sugestivnom proznom obradom, izričito se okrivljuje Nikšić. Mjestimično se Nikšić pojavljuje i kao izravni nalogodavac te izbornik žrtava. Tako Goldstein piše da:

mnije vjerojatno da bi se dr. Ante Nikšić, čovjek oprezan i rutinirani oportunist, odvažio izdati naredenje za tri prva ubojstva, a da pri tome nije imao neko zalede ili pokrice odozgo [...] navodno se sastajao is Didom Kvaternikom, koji je u to vrijeme barem dva puta bio u Karlovcu. Nikšiću je samo preostalo izabrati prve žrtve«.90

Sâm Židovec odnosno preko njega istražitelji uglavnom su se ograničili na Vujičića osobno i na optužbu da se radilo o inicijativi ili ideji natuknutoj omladincima. Odluku o zločinu i njegovoj provedbi Židovec je pripisao omladincima i tako izbjegao da se bavi kriminalistički relevantnim pojedinostima. Podatak o Nikšićevu »navodnom sastanku« s Didom Kvaternikom potječe iz Židovčeve Autobiografije i odnosi se na vrijeme kada se Židovec nalazi u svojevrsnoj političkoj izolaciji očekujući rasplet oko svoje predstavke, dakle ne prije nego otprilike dva tjedna nakon Vujičićeva ubojstva. $^{91}$

Nakon objave Goldsteinove knjige Nikšićeva se navodna krivnja za Vujičićevu smrt više ne smatra upitnom pa tako Karlovački leksikon 2008. za nj samo kratko navodi: »Ante Nikšić [...] isprva jugosl[avenski] opredijeljen [...] je [uoči imenovanja županom] inicirao prve likvidacije nekih uglednih karl[ovačkih]. građana (odvjetnik Vujičić i drugi) «.92

Hrvatski institut za povijest izdao je 2009. studiju Davora Kovačića o redarstveno-obavještajnom sustavu NDH, u predgovoru koje se prenosi »mišljenje nekih istraživača» da Židovčevu Autobiografiju treba smatrati »vjerojatno najvrjednijim svjedočanstvom jednoga od istaknutijih sudionika unutar Ustaškog pokreta 1941.1945. « $^{93}$ Studija se stoga u opisu slučaja Vujičić uglavnom zadovoljava Židovčevim opisom događaja i upotpunjuje ga nekim tvrdnjama profesora Radeke. ${ }^{94}$

90 Goldstein, str. 82-83.

91 Dosje Židovec, str. 62. Teško je zamisliti da bi Židovec u razdoblju kad je operativno »vladao《 Karlovcem sjedio za jednim kavanskim stolom, a Kvaternik s podređenim dužnosnicima za drugim. Usp. Goldstein, str. 117.

92 Karlovački leksikon, Zagreb, Školska knjiga 2008., str. 419.

93 Davor Kovačić, Redarstveno-obavještajni sustav Nezavisne Države Hrvatske od 1941. do 1945. godine, Zagreb, Hrvatski institut za povijest, 2009., str. 46.

94 Dosje Židovec, str. 343. 
Dijelovi Dosjea Židovec - Autobiografija i zapisi arhiviranih saslušanja - objavljeni su krajem 2017. uz opširan i informativan predgovor, u ovdje često citiranoj knjizi Željka Karaule Pavelićev diplomat na jugoistoku Europe. I u njoj je međutim izostala šira kritička raščlamba tvrdnji iznesenih u specifičnim zatvorskim uvjetima preuzetih obveza prema istražiteljima, a nisu prenesene ni optužnica ni presude Židovcu.

\section{Zaključak}

Slučaj Vujičić skupni je naziv za ubojstvo trojice Srba u Karlovcu nakon nešto više od tri tjedna postojanja $\mathrm{NDH}$, ali može poslužiti i kao primjer za to na koji se način istina gubila u različitim sustavima vlasti u idućih tri četvrt stoljeća. Svaki je sustav traženje istine podredio svojoj partikularnoj logici i potrebama trenutka. Prešućivanje dokumentirane stvarnosti, odnosno kumulacija tumačenja na osnovu nepotpunih ili iskrivljenih materijala, doveli su do rezultata koji se postupno afirmira kao neprijeporna, znanstveno utvrđena činjenica.

Za povijesnu znanost to nije nimalo nova situacija - ona se uvijek iznova bavi ljuštenjem prividno točnih opisa kako bi se doprlo do skrivenih odnosa, namjera i vrjednovanja. Često se pri tome zaboravlja da ni taj proces nije neovisan o društtenim situacijama i političkim silnicama u okviru kojih djeluje. Aktualno tumačenje slučaja Vujičić gotovo je u potpunosti utemeljeno na autobiografskom tekstu jednoga od neposrednih aktera drame, Vladimira Židovca, nastalom u zatočeništvu, pod psihološkim pritiskom, neposrednom prijetnjom smrti i u okolnostima pristanka na suradnju s istražiteljima - zacijelo i pod njihovim uvjetima baratanja izvorima kako bi se postigao zadani cilj. Prikaz te vrste, ma koliko zanimljiv kao dokument vremena, neuporabiv je kao vjerodostojan povijesni izvor bez detaljne raščlambe situacije $u$ kojoj je nastao i partikularnih interesa svjedoka odnosno zatočenika, a posebice potreba režima pod čijom je kontrolom nastao.

Namjera ovoga rada bila je istaknuti nekoliko ključnih informacija, nepoznatih, prešućenih ili izuzetih iz materijala udbaške istrage, koje mogu baciti novo svjetlo na dinamiku događaja oko ubojstva Vujičića i drugova. Ciljana udbaška istraga željela je zločin pripisati vodećem karlovačkom ustaši Anti Nikšiću, bez obzira na indicije kako je upravo on jedini neposredno reagirao na zločin nad svojim srpskim prijateljem.

Zbog mnogih nerasvijetljenih pojedinosti ta se reakcija ne može uzeti kao neki apsolutni dokaz njegove nevinosti, ali može poslužiti kao dio mozaika o Nikšićevoj ustaškoj karijeri u kojoj su zamjetni neuspješni pokušaji širenja političke baze i primirivanja sukoba sa Srbima preko pokušaja suradnje s Hrvatskom seljačkom strankom. 


\title{
UDBA SECRET POLICE FILE AS A HISTORICAL SOURCE - THE VUJIČIĆ CASE
}

\author{
Branko Salaj \\ branko.salaj@gmail.com
}

\begin{abstract}
In early May 1941, three Serbs were killed by a group of young Ustasha militiamen assigned to the local headquarters of the Ustasha movement in the Croatian city of Karlovac. The affair, known as »the Vujičić case« after its best known victim, attorney and politician Milan Vujičić, was hushed up at that time, but the case left a deeper imprint on historical studies than some of the larger atrocities committed during the period. The case was reopened in early 1947, upon the extradition of Vladimir Židovec to Yugoslavia. Židovec was the secretary of the local Ustaša HQ at the time of the crime, and afterwards a diplomat in the Independent State of Croatia (ISC). Subjected to harsh interrogation by the Yugoslav Udba secret police, Židovec offered to collaborate and authored a lengthy but tainted testimony. He claimed that his antagonist and formal local superior Ante Nikšić, afterwards an ISC diplomat and minister of the interior, initiated the crime. In spite of various important deficiencies of the inquiry, the thesis that Nikšić had instigated the murder of his personal friend Vujičić has been reiterated over the years. It has been incorporated into reference manuals as a proven fact, and has even been contextualized on a larger scale. This article therefore strives to reconsider the case on the basis of some new elements. While offering no final answers, it points to various incongruences of the present interpretation.
\end{abstract}

Keywords: Independent State of Croatia; Karlovac; Milan Vujičic; Ante Nikšić; Vladimir Židovec; Udba 